Brazilian Journal

of Chemical

ISSN 0104-6632

Engineering

\title{
EFFECTIVE ALKALINE PEROXIDE OXIDATION PRETREATMENT OF SHEA TREE SAWDUST FOR THE PRODUCTION OF BIOFUELS: KINETICS OF DELIGNIFICATION AND ENZYMATIC CONVERSION TO SUGAR AND SUBSEQUENT PRODUCTION OF ETHANOL BY FERMENTATION USING Saccharomyces cerevisiae
}

\author{
A. O. Ayeni ${ }^{1,2}$, J. A. Omoleye ${ }^{2}$, F. K. Hymore ${ }^{2}$ and R. A. Pandey ${ }^{1 *}$ \\ ${ }^{1}$ Environmental Biotechnology Division, National Environmental Engineering Research Institute, \\ Nehru Marg, Nagpur 440020 Maharashtra, India. \\ Phone: + 917122240097; Fax: + 917122249961 \\ "E-mail: ra_pandey@neeri.res.in; augustine.ayeni@covenantuniversity.edu.ng \\ ${ }^{2}$ Department of Chemical Engineering, Covenant University, km 10 Idiroko Road, Canaan land Ota, Nigeria.
}

(Submitted: December 26, 2014 ; Revised: March 19, 2015 ; Accepted: April 15, 2015)

\begin{abstract}
Shea tree sawdust delignification kinetic data during alkaline peroxide pretreatment were investigated at temperatures of $120^{\circ} \mathrm{C}, 135^{\circ} \mathrm{C}$, and $150^{\circ} \mathrm{C}$. The activation energy during delignification was $76.4 \mathrm{~kJ} / \mathrm{mol}$ and the Arrhenius constant was calculated as $8.4 \times 10^{6}$ per min. The reducing sugar yield for the treated to the untreated biomass was about 22 -fold. Enzymatic hydrolysis conditions studied were; time $(72 \mathrm{~h}$ and $96 \mathrm{~h}$ ), substrate concentration $(20,30,40$, and $50 \mathrm{~g} / \mathrm{L})$, and enzyme loadings $(10,25,40,50 \mathrm{FPU} / \mathrm{g}$ dry biomass), which showed the optimum conditions of $96 \mathrm{~h}, 40 \mathrm{~g} / \mathrm{L}$, and $25 \mathrm{FPU} / \mathrm{g}$ dry biomass at $45^{\circ} \mathrm{C}$ hydrolysis temperature. At the optimized enzymatic hydrolysis conditions, the reducing sugar yield was $416.32 \mathrm{mg}$ equivalent glucose/g treated dry biomass. After $96 \mathrm{~h}$ fermentation of treated biomass, the ethanol obtained at $2 \%$ effective cellulose loading was $12.73 \mathrm{~g} / \mathrm{L}$. Alkaline peroxide oxidation pretreatment and subsequent enzymatic hydrolysis improved the ethanol yield of the biomass.

Keywords: Alkaline peroxide oxidation; Fermentation; Vitellaria paradoxa; Optimization; Pretreatment; Enzymatic hydrolysis.
\end{abstract}

\section{INTRODUCTION}

Bioenergy is a renewable resource because of the short life cycle compared to the fossil fuel alternative. Plants and plant-derived materials (biomass) are important feed-stocks for lignocellulosic biofuels. The biomass cell wall structure is rigid and hard to break down. Pretreatment is an important tool for lignocelluloses bioconversion processes and is required to alter the biomass structure to make cellulose more accessible to the enzymatic complex (Mosier et al., 2005). Pretreatments release cellulose from amorphous lignin and hemicellulose complexes. Wood and other lignocellulosic biomass con-

*To whom correspondence should be addressed 
sist of four major chemical components: cellulose, lignin, hemicellulose, and extractives. In ethanol production from lignocellulose, it is necessary to remove the lignin and extractives from the wood, leaving primarily the wood polymer carbohydrates, cellulose and hemicellulose. There are bottlenecks for efficient ethanol production from lignocellulosic materials, among these the presence of lignin surrounding the cellulose acts as a physical barrier, reducing the available sites for enzymatic hydrolysis (Krishna and Chowdary, 2000; Kim and Lee, 2006). Lignin is responsible for the integrity, structural rigidity, and prevention of the swelling of lignocelluloses. Lignin constitutes the most recognized factor that is responsible for the resistance of lignocellulosic materials to enzymatic degradation by limiting the enzyme accessibility. Alkaline peroxide oxidation pretreatment is one method that has been discovered to improve the accessibility of lignocellulosic biomass to cellulolytic enzymes (Kumar et al., 2009). This pretreatment approach has been studied extensively (Ayeni et al., 2013b; Wei and Cheng, 1985; Gould, 1984; Gould et al., 1989; Qi et al., 2009; Li et al., 2013). Studies on cellulosic biomass delignification (lignin removal) usually involve two different approaches, assuming that the lignocellulosic material contains one type of lignin, and that the material is composed of several species (usually initial, bulk, and residual lignin) dissolving at different rates (Kleinert, 1975; Springer, 1963). The most usual approach is to assume that the different lignin species react consecutively according to first-order kinetics. In the several species of lignin approach, the different phases observed during delignification correspond to changes in the mechanism that controls the reaction rate of the overall process (Parajó et al., 1995; Vázquez et al., 1995). The chemical kinetics of alkaline pretreatment processes have been demonstrated in the scientific literature (Kleinert, 1966; Kim and Holtzapple, 2006). The Shea tree, Vitellaria paradoxa, is rich in carbohydrate and lignin contents (Ayeni et al., 2014). The Shea tree, which furnishes a woody (hardwood) lignocellulosic material, is typically a savannah woodland tree species. This tree is small to medium-sized, 10-15 m tall with a diameter ranging from 0.3 to $1 \mathrm{~m}$. It is native to African countries. It occurs on an estimated 1 million $\mathrm{km}^{2}$ between western Senegal and northwestern Uganda. The exotic species is found in the Dominican Republic and Honduras (Sallé, 1991). The trunk of the Shea tree makes excellent charcoal and is favoured as a source of high quality wood fuel once the tree has passed the fruit bearing age (Kristensen and Lykke, 2003). The carbohydrates (cellu- lose and hemicellulose) are suitable precursors for enzymatic hydrolysis conversion to fermentable sugars. The high lignin content also makes the Shea tree wood a suitable material to produce other fuels and chemicals. Lignin can also be burnt for its high heating value (Ladisch, et al. 1979).

Previously (Ayeni et al., 2013b), we achieved up to $60 \%$ cellulose conversion, $80 \%$ hemicellulose solubilization, and 17\% lignin removal with an alkaline peroxide assisted wet air oxidation (APAWAO) pretreatment of Shea tree sawdust (under optimized conditions: reaction temperature of $150{ }^{\circ} \mathrm{C}, 45 \mathrm{~min}$ reaction time, $1 \% \mathrm{H}_{2} \mathrm{O}_{2}(\mathrm{v} / \mathrm{v})$, and $1.0 \mathrm{MPa}$ air pressure). This was compared to alkaline peroxide oxidation (APO) pretreatment (reaction temperature of $150{ }^{\circ} \mathrm{C}, 45 \mathrm{~min}$ reaction time, $\left.1 \% \mathrm{H}_{2} \mathrm{O}_{2}(\mathrm{v} / \mathrm{v})\right)$ with $53.86 \%$ cellulose conversion, $70 \%$ hemicellulose solubilization and $11 \%$ lignin removal. We also reported that the APAWAO conditions enhanced the enzymatic convertibility of treated samples to reducing sugars from an initial $177.89 \mathrm{mg}$ equivalent glucose/g dry biomass (APO conditions) to $263.49 \mathrm{mg}$ equivalent glucose/g dry biomass. In this study, the kinetics of delignification were evaluated during the pretreatment APO process at three operating temperatures. The enzymatic convertibility (using cellulase and $\beta$-glucosidase enzymes and a 4-day hydrolysis period) under the optimized pretreatment conditions $\left(150{ }^{\circ} \mathrm{C}, 45 \mathrm{~min}, 1 \% \mathrm{H}_{2} \mathrm{O}_{2}(\mathrm{v} / \mathrm{v})\right.$ and $1.0 \mathrm{MPa}$ air pressure) was investigated at varying dry biomass loadings of $2,3,4$, and $5 \%$ with corresponding increases in enzyme loadings. Enzymatic conversions without $\beta$-glucosidase supplements were also considered for hydrolysis at $45{ }^{\circ} \mathrm{C}$ for 4 days. Furthermore, the ferment ability of the treated solids using simultaneous saccharification and fermentation methods was evaluated.

\section{MATERIALS AND METHODS}

\section{Raw Material}

Raw material preparation from the field to the laboratory before compositional analysis and the pretreatment steps have been described extensively elsewhere (Ayeni et al., 2013a). The tree was harvested (in early April, 2010) from the forest around Idanre town $\left(6^{\circ} 51^{\prime} \mathrm{N} 5^{\circ} 06^{\prime} \mathrm{E}\right)$ and the sawdust was collected from the central processing unit of the local sawmill (Ilepa, Ifo town, south west, Nigeria) in late June, 2010. Samples used in all the experiments were sieved to pass through mesh 14 (British Standard Sieve specifications) and be retained by mesh 80 . 
The average particle sizes therefore varied between 0.09 to $0.51 \mathrm{~mm}$, which made up $73 \%$ of the harvested raw material. The screening of dried raw material was carried out to minimize the effects of very fine particles (which appeared in the form of dust) on pretreatment. The dried (using a convection oven at $105{ }^{\circ} \mathrm{C}$ for $3 \mathrm{~h}$ to a dry matter content of $88 \%$ ) and sieved materials were stored in plastic bottles capped tightly and kept at $26{ }^{\circ} \mathrm{C}$. The materials were used shortly after. The chemicals used in this study were acetone, calcium hydroxide, D-glucose, and ethanol, and were purchased from ThermoFisher Scientific, India, hydrogen peroxide from E-Merch, India, and $\beta$-glucosidase from Himedia Laboratories, India. Trichoderma reesei cellulases (in the form of a brown liquid) was kindly provided by $\mathrm{M} / \mathrm{s}$ Zytex, Mumbai, India. Deionized water was used in all experiments.

\section{Experimental Set Up}

Response surface methodology (RSM) was adopted for the optimization of the process variables in the alkaline peroxide oxidation (APO) pretreatment of Vitellaria paradoxa sawdust based on central composite design (CCD) experiments. A $2^{3}$ five level CCD with central and axial points was used to develop the statistical model for the optimization of process variables (Ayeni et al., 2013b). The CCD design was made up of 20 base runs ( 8 cube points, 4 center points in the cube, 6 axial points, and 2 center points on the axial). Figure 1 shows the schematic diagram of the pretreatment experimental set up.
The pretreatment process experimental set up consisted of a $1.8 \mathrm{~L}$ volume batch Parr reactor (Model-4578, Floor stand HP/HT, Parr Instruments, IL., USA) equipped with double six-blade turbine impellers with external heating embedded in a jacket. An independent controller maintained the temperature in the reactor regulated to within $\pm 2{ }^{\circ} \mathrm{C}$ of the set point values with constant stirring at $21 \mathrm{rad} / \mathrm{s}$. Oxidative pretreatments were achieved by the use of $\mathrm{Ca}(\mathrm{OH})_{2}-\mathrm{H}_{2} \mathrm{O}_{2}$ solution. Lime loadings varied between $9.0 \mathrm{~g}$ to $30.0 \mathrm{~g}$ with corresponding volumes of $\mathrm{H}_{2} \mathrm{O}_{2}$ based on the central composite design. The combination of $\mathrm{Ca}(\mathrm{OH})_{2}-\mathrm{H}_{2} \mathrm{O}_{2}$-air pressure was achieved at $1.0 \mathrm{MPa} .30 \mathrm{~g}$ of dry substrate were mixed with $500 \mathrm{~mL}$ of distilled water containing $\mathrm{H}_{2} \mathrm{O}_{2}$. The slurry was adjusted to $\mathrm{pH} 11.5$ with $\mathrm{Ca}(\mathrm{OH})_{2}$ accordingly. Each reaction was terminated by running cold water through the internal loops. After the specified reaction time, the reactor and slurry were allowed to cool to ambient temperature. The pretreated slurry was separated into the solid and liquid fractions by vacuum filtration. The solid fraction was washed with water until the $\mathrm{pH}$ approached 7. A portion of the wet pretreated biomass was weighed and dried to a constant weight at $105^{\circ} \mathrm{C}$ in a convection oven in order to determine the total solid left after pretreatment and the amount of wet treated biomass in terms of dry biomass required for the enzymatic hydrolysis and fermentation steps (Dowe and McMillian, 2008). The remaining portion of the wet pretreated biomass was used in the enzymatic digestibility and ferment ability of biomass, as well as the delignification of the raw biomass.

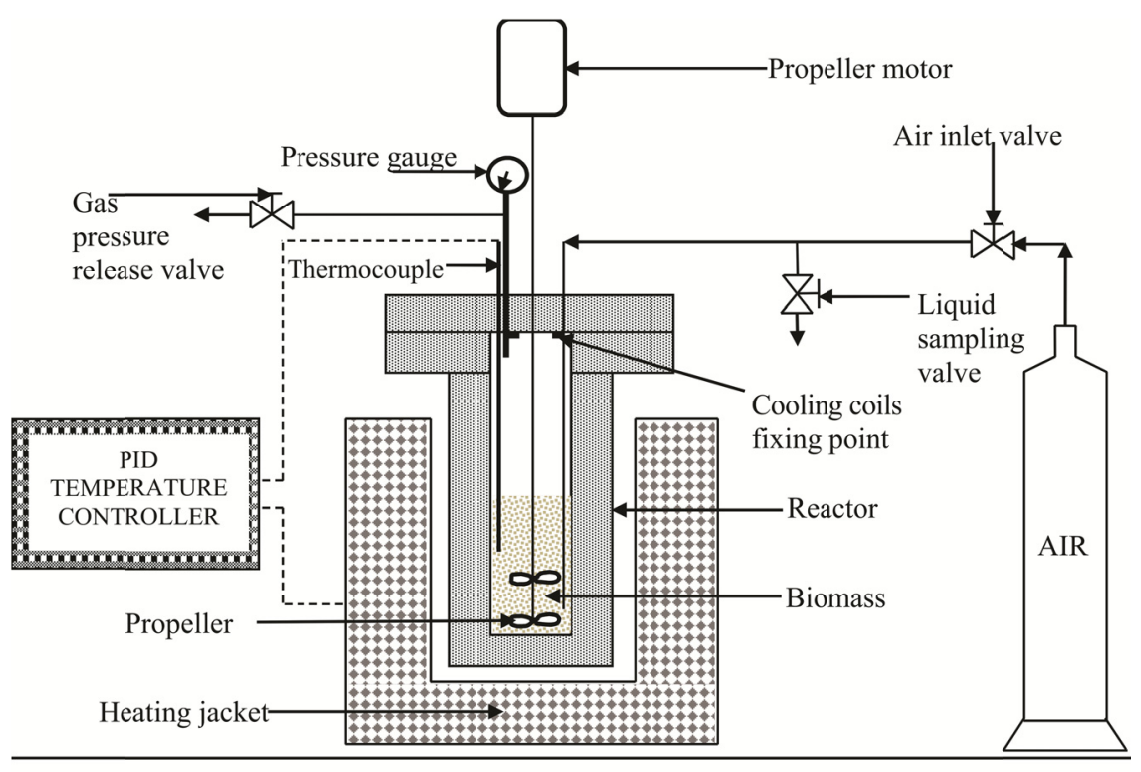

Figure 1: Schematic diagram of the pretreatment reactor setup. 


\section{Delignification Parameters}

Kinetic data for the pretreatment were evaluated at different temperatures $\left(120^{\circ} \mathrm{C}, 135^{\circ} \mathrm{C}\right.$, and $\left.150^{\circ} \mathrm{C}\right)$ and a kinetic model for the wood waste delignification with lime as a function of temperature was determined. For each of these isothermals, the composition of pretreated sawdust was determined at reaction times 20, 25, 30, 35, 40, and $45 \mathrm{~min}$. Pretreatment reaction kinetics is an important tool for the economics of a process since reactor volume, and hence the capital equipment requirement, is said to be proportional to the residence time in the reactor (Li et al., 2013). The kinetics of delignification were studied by following the amount of lignin removed from the pretreated solids (Table 1) and analyzed on the basis of the proportion of the total lignin removed with time (Esteves et al., 2005).

Table 1: Lignin remaining (\%w/w) based on dry weight of pretreated biomass.

\begin{tabular}{|c|c|c|c|}
\hline Time (min) & $\mathbf{1 2 0}^{\circ} \mathbf{C}$ & $\mathbf{1 3 5}^{\circ} \mathbf{C}$ & $\mathbf{1 5 0}^{\circ} \mathbf{C}$ \\
\hline 45 & 25.98 & 26.39 & 26.52 \\
40 & 26.23 & 27.07 & 27.03 \\
35 & 26.27 & 27.63 & 27.34 \\
30 & 26.31 & 28.17 & 27.65 \\
25 & 26.34 & 27.90 & 28.05 \\
20 & 26.37 & 27.61 & 28.45 \\
\hline
\end{tabular}

The reaction was considered to be irreversible and to follow a second order as:

$$
\text { Lignin }(\mathrm{L})+\text { Oxygen }(\mathrm{O}) \rightarrow \text { Product }(\mathrm{P})
$$

The reaction rate, $\mathrm{r}_{\mathrm{L}}$ could be expressed as:

$$
-\mathrm{r}_{\mathrm{L}}=-\mathrm{dL} / \mathrm{dt}=\mathrm{k} \cdot \mathrm{L} \cdot \mathrm{O}
$$

If oxygen is in excess, the concentration of oxygen can be considered to be constant, giving the equation:

$$
-\mathrm{r}_{\mathrm{L}}=-\mathrm{dL} / \mathrm{dt}=\mathrm{k} \cdot \mathrm{L}
$$

The reaction is now pseudo first-order and the relationship can be expressed as:

$$
-\mathrm{dL} / \mathrm{dt}=\mathrm{k} \cdot \mathrm{L}
$$

where $\mathrm{dL} / \mathrm{dt}=$ lignin removal rate; $\mathrm{k}=$ chemical reaction rate constant; $\mathrm{L}=$ residual lignin after pretreatment.

It has also been established that alkaline pulping is a first order, pseudo homogenous reaction and that the rate of change of lignin removed per unit mass of solid is related to the product of the amount of lignin remaining in the solid mass and the concentration of the alkali (Correira et al., 2001). Integrating Equation (4) shows it is a straight line relationship:

$\ln \left(\mathrm{L} / \mathrm{L}_{0}\right)=-\mathrm{k} \mathrm{t}+\mathrm{C}$

where $\mathrm{L}=$ total lignin content at time $\mathrm{t}, \mathrm{L}_{0}=$ total lignin content at time $\mathrm{t}=0$

The rate constant, $\mathrm{k}$, is obtained from the linear regression coefficient. The temperature dependence of the rate constant is characterized by the value of the energy of activation (Nelson, et al., 1987). The energy of activation is the minimum energy that must be possessed by reacting molecules before the reaction can occur. $\mathrm{k}$ is related to temperature by the Arrhenius Law:

$$
\mathrm{k}=\mathrm{A} \exp ^{-\mathrm{Ea} / \mathrm{RT}}
$$

where $\mathrm{A}=$ Arrhenius constant; $\mathrm{E}_{\mathrm{a}}=$ activation energy; $\mathrm{R}=$ gas constant $=8.314 \mathrm{~kJ} / \mathrm{mole} \cdot \mathrm{K} ; \mathrm{T}=$ absolute temperature $(\mathrm{K})$.

The activation energy $\left(\mathrm{E}_{\mathrm{a}}\right)$ of delignification was calculated for each kinetically homogeneous lignin fraction from the logarithmic form of the Arrhenius equation ( $\ln \mathrm{k}=\ln \mathrm{A}-\mathrm{E}_{\mathrm{a}} / \mathrm{RT}$ ) by plotting $\ln \mathrm{k}$ against $1 / \mathrm{T}$ with the slope equal to $\mathrm{E}_{\mathrm{a}} / \mathrm{R}$ (Figure 2(B)) (Esteves et al., 2005), ln A is the intercept from where the Arrhenius constant is calculated. The kinetics of delignification was established by assuming the material contains one type of lignin.

\section{Material Balances and Biomass Composition}

Untreated and treated samples were repeatedly washed with fresh distilled water until the decanted water became colourless. The total dry weight of the sample was measured before and after pretreatment and washing. Dry weight measurement for material balances was described previously based on drying the biomass at $105{ }^{\circ} \mathrm{C}$ for $6 \mathrm{~h}$ (Ayeni et al., 2013a; Ayeni et al., 2013b). Extractives and hemicellulose contents were measured as described previously (Ayeni et al., 2013b). Extractives determination was carried out by the means of a Soxhlet extractor. 300 $\mathrm{mL}$ of acetone was used as solvent on $5 \mathrm{~g}$ of dry raw and treated biomass. The temperature and time during extraction for the boiling and rising stages equalled $70^{\circ} \mathrm{C}$ and $25 \mathrm{~min}$, respectively, for a $4 \mathrm{~h}$ run period. After extraction, the sample was air dried for a few minutes at room temperature and further dried 
at $105{ }^{\circ} \mathrm{C}$ in a convection oven. The extractives content was calculated as the difference in weight between the raw and extracted material (Ayeni et al., 2013b; Blasi et al., 1999; Li et al., 2004, Lin et al., 2010). Mineral components were determined by ashing at $575{ }^{\circ} \mathrm{C}$ for $6 \mathrm{~h}$. The hemicellulose content was determined by transferring $1 \mathrm{~g}$ of dried biomass from the extractive analysis into a $250 \mathrm{~mL}$ Erlenmeyer flask. $150 \mathrm{~mL}$ of $0.5 \mathrm{~mol} / \mathrm{L} \mathrm{NaOH}$ solution was added to the dried biomass. The mixture was boiled for 3 hours and 30 minutes with distilled water. The residue was dried to a constant weight at $105^{\circ} \mathrm{C}$ and later cooled in a desiccator and weighed. The hemicellulose content was calculated as the difference between the sample weight before and after this treatment (Ayeni et al., 2013b; Blasi et al., 1999; Li et al., 2004, Lin et al., 2010). Lignin content was determined as the summation of Klason lignin and acid soluble lignin on the extractive free samples by the National Renewable Energy Laboratory standard procedures (Sluiter et al., 2008). Cellulose content was determined by difference, assuming only ash, extractives, hemicelluloses, lignin were present in the biomass (Ayeni et al., 2013b; Blasi et al., 1999; Li et al., 2004, Lin et al., 2010). The raw biomass compositional analysis, percent weight by weight, estimated cellulose content of $45.90 \%$, hemicellulose: $20.31 \%$, lignin: $29.90 \%$, extractives: $1.89 \%$, and ash: $2.04 \%$.

\section{Enzymatic Conversion of Treated and Untreated Biomass}

The action of cellulase and $\beta$-glucosidase enzymes on the treated and untreated biomass was evaluated. In $30 \mathrm{~mL}$ culture tubes (arranged in parallel for sampling different time points) were added 20, 30,40 , and $50 \mathrm{~g} / \mathrm{L}$ wet treated and washed-only untreated biomass samples. A commercial preparation of Trichoderma reesei cellulases (activity of $57.8 \mathrm{FPU} / \mathrm{mL}$ ) and $\beta$-glucosidase (Extra pure, CAS No.: 9001-22-3, with an activity of $10 \mathrm{IU} / \mathrm{mg}$ solid) were added at loadings which corresponded to the increased substrate concentrations (Table 2).

The activity of the cellulase enzymes was determined in terms of filter paper units. A linear glucose standard curve using the absolute amounts of glucose standards $(\mathrm{mg} / 0.5 \mathrm{~mL})$ was plotted against absorbance at $540 \mathrm{~nm}$. This graph was used to determine the concentration of reducing sugars in the sample tubes, which had to be incubated with cellulase enzyme solutions of varying dilutions at $50{ }^{\circ} \mathrm{C}$ for 60 $\mathrm{min}$. The value of $2.0 \mathrm{mg}$ of reducing sugar as glucose from $50 \mathrm{mg}$ of filter paper (4\% conversion) in 60 min was used for calculating filter paper cellulase units (FPU). (Ghose, 1987). $\beta$-glucosidase activity was determined by the method described by Bailey and Linko (1990).

An appropriate volume of distilled water was added until the $10 \mathrm{~mL}$ final volume including $0.05 \mathrm{M}$ sodium acetate buffer, $\mathrm{pH}$ 4.8. The reaction mixture was placed in an orbital shaking incubator (Scigenics Biotech, Chennai, India) maintained at a temperature of $45^{\circ} \mathrm{C}$ and at $14 \mathrm{rad} / \mathrm{s}$. At specified periods, culture tubes were removed and $1 \mathrm{~mL}$ aliquot samples were taken for sugar analysis (Dowe and McMillan, 2008). Hydrolyzed samples were centrifuged at 2254 gravities for $5 \mathrm{~min}$ to remove residual solids and total reducing sugars was quantified with DNS (3,5dinitrosalicylic acid) assay (Ayeni et al., 2013a; Miller, 1959).

Table 2: 4-D effect of substrate concentration with corresponding increase in enzyme concentration and incubation period on the enzymatic saccharification of pretreated sawdust; conditions of $150^{\circ} \mathrm{C}, 1 \% \mathrm{H}_{2} \mathrm{O}_{2}$, 1.0 MPa, and $45 \mathrm{~min}$.

\begin{tabular}{|l|r|r|r|r|r|r|r|r|}
\hline \multicolumn{9}{|c|}{ Substrate concentration (g/L) } \\
\hline
\end{tabular}

${ }^{a}$ Cellulase enzyme loading. ${ }^{b} \beta$-glucosidase loading. ${ }^{\mathrm{c}}$ cellulase enzyme loadings remained the same as with supplemental $\beta$-glucosidase. Enzymatic hydrolysis conditions: incubation temperature $45{ }^{\circ} \mathrm{C}, \mathrm{pH} 4.8$, RS-Reducing sugar (mg equivalent glucose/g dry biomass, D- \% Digestibility. 
Calibration curves (using glucose as a standard) were used to determine the reducing sugar concentrations (Chang et al., 1998). The sample was diluted properly so that the measured absorbance was in the linear range. Reducing sugar yields were expressed as mg equivalent glucose/g dry substrate (treated substrate as cellulose and hemicellulose). Furthermore, hydrolysis results (\% digestibility; as substrate conversion), were expressed in terms of the theoretical or total polysaccharide in the treated substrate (Yoo et al., 2011).

$$
\% \text { Digestibility }=\frac{\begin{array}{c}
\text { Reducing sugar obtained } \\
(\mathrm{g} / \mathrm{g}) \times 0.9 \times 100
\end{array}}{\left(\begin{array}{c}
\text { Treated substrate } \\
\text { (cellulose }+ \text { hemicellulose }) \mathrm{g} / \mathrm{g}
\end{array}\right.}
$$

Wet treated biomass was used for the enzymatic hydrolysis and fermentation steps. Sugar yields were also expressed as dry biomass based on equivalent material balance of wet treated sample (Dowe and McMillan, 2008).

\section{Ethanol Fermentation Process}

The sugar from the pretreatment process solid fraction was fermented to ethanol through simultaneous saccharification and fermentation (SSF) by Saccharomyces cerevisiae kindly provided by Purti Power and Sugar Ltd., Distillery Division, Nagpur, India. The $S$. cerevisiae inoculum culture medium was prepared aseptically in a $250 \mathrm{~mL}$ shaking flask covered with a cotton stopper with $100 \mathrm{~mL}$ of medium containing $3 \mathrm{~g} / \mathrm{L}$ malt extract, $3 \mathrm{~g} / \mathrm{L}$ yeast extract, $5 \mathrm{~g} / \mathrm{L}$ peptone, and $10 \mathrm{~g} / \mathrm{L}$ glucose, and incubated on a rotary shaker at 130 revolution per minute and $32 \pm$ $2.0{ }^{\circ} \mathrm{C}$ for $24 \mathrm{~h}$. All media were sterilized by autoclaving at $121^{\circ} \mathrm{C}$ for $30 \mathrm{~min}$. The cells were harvested for SSF fermentation to a final optical density (OD) of 0.6 measured at $600 \mathrm{~nm}$ (Dowe and McMillan, 2008). SSF was performed under anaerobic condition, made possible by making the rubber stoppered flasks air-tight with Teflon tape and thereafter covered with aluminum foil, in sterile $250 \mathrm{~mL}$ shaking flasks with the incubator shaker at $30 \pm 2.0{ }^{\circ} \mathrm{C}$ for $96 \mathrm{~h} .5 \mathrm{~mL}$ of inoculum culture were added into the $50 \mathrm{~mL}$ working volume, sterilized for the fermentation of the pretreated solids. The $\mathrm{pH}$ of the medium was adjusted to $4.8 \pm 0.2$ with $0.05 \mathrm{M}$ citrate buffer. With a total sample size of $50 \mathrm{~g}$ (total working volume for fermentation was $50 \mathrm{~mL}$ ), the desired cellulose effective loadings of $2 \%(\mathrm{w} / \mathrm{w})$ and $3 \%(\mathrm{w} / \mathrm{w})$ were considered, which were equivalent to $1.0 \mathrm{~g}$ and $1.5 \mathrm{~g}$ of cellulose, respectively, in treated substrate. The cellulase loading (filter paper activity $=57.8 \mathrm{FPU} / \mathrm{mL}$ ) was 25 FPU/g cellulose and the concentration of yeast ( $\mathrm{Sac}$ charomyces cerevisiae) inoculum was $10 \%(\mathrm{v} / \mathrm{v})$. At the end of fermentation period, $5 \mathrm{~mL}$ of mixture were removed and centrifugation was performed at 4,500 revolution per minute for $5 \mathrm{~min}$ (Dowe and McMillan, 2008). The supernatant after centrifugation was used for the ethanol estimation.

The ferment ability of the pretreated solids was characterized by the equation (Dowe and McMillan, 2008):

$\%$ theoretical ethanol yield $=$

$$
\frac{[\mathrm{EtOH}]_{\mathrm{f}}-[\mathrm{EtOH}]_{0}}{0.51(\mathrm{f}[\text { Biomass }] 1.111)} \times 100 \%
$$

where $[\mathrm{EtOH}]_{\mathrm{f}}=$ ethanol concentration at the end of the fermentation $(\mathrm{g} / \mathrm{L})$ minus any ethanol produced from the enzyme and medium,

$[\mathrm{EtOH}]_{0}=$ ethanol concentration at the beginning of the fermentation $(\mathrm{g} / \mathrm{L})$, which should be zero, [Biomass] $=$ dry biomass concentration at the beginning of the $\operatorname{SSF}(\mathrm{g} / \mathrm{L}), f=$ Cellulose fraction of the dry biomass $(\mathrm{g} / \mathrm{g})$,

$0.51=$ Conversion factor for glucose to ethanol based on the stoichiometric biochemistry of the ethanol fermentation,

1.111 = factor that converts cellulose to equivalent glucose.

The ethanol yield was calculated as a percentage of the theoretical yield on the basis of the total effective cellulose in the pretreated material, in other words, the \% theoretical ethanol yield can also be given as $\%$ cellulose conversion. The control fermentation (without biomass samples) was performed and the result was subtracted from the test fermentations for each biomass loading.

Ethanol analysis was carried out from the absorbance of the sample using the dichromate assay method (Ayeni et al., 2014; Bennet, 1971); acid dichromate solution $\left(0.1 \mathrm{M} \mathrm{Cr}_{2} \mathrm{O}_{7}^{2-}\right.$ in $\left.5 \mathrm{M} \mathrm{H}_{2} \mathrm{SO}_{4}\right)$ was prepared by dissolving $7.5 \mathrm{~g}$ of potassium dichromate in $70 \mathrm{~mL}$ of dilute sulfuric acid and the final volume was adjusted to $250 \mathrm{~mL}$ with deionized water. The standard curve was made by adding $300 \mu \mathrm{L}$ of ethanol solution to beaker containing $3 \mathrm{~mL}$ of acid dichromate. The beakers were covered and sealed with parafilm and kept at room temperature for 30 min. The absorbance was recorded at $590 \mathrm{~nm}$ on spectrophotometer (UV-1800 Shimadzu, Japan). 


\section{RESULTS AND DISCUSSION}

\section{Determination of the Kinetic Parameters for Delig- nification}

During the pretreatment process, lignin removal between 8.1 and $12.3 \%$ was observed under the experimental conditions. The delignification did not exceed $17 \%$ under enhanced pretreatment conditions (Ayeni, et al., 2013b). The proportions of lignin removed calculated for the three different process temperatures suggested high compositional stability within the tested values. The hindrance posed to the ease of delignification during pretreatment may be connected with the high lignin content (29.9\%) in the raw biomass (Ayeni et al., 2013b). High delignification may also have been hindered because of the type of catalyst used $\left(\mathrm{Ca}(\mathrm{OH})_{2}\right)$. The first-order kinetic behaviour of delignification process is shown in Figure 2(A) and the values of rate constants obtained from the slope of the straight lines are presented in the same figure. The results indicated that the rate constants increased with increasing temperature. At increasing temperatures there were more collisions of the reactants, which further increased the rate of reaction.

Lignin remaining at the three operating temperatures (calculated on dry weight of treated biomass) were estimated based on the linear regressions; $150{ }^{\circ} \mathrm{C}, \mathrm{y}=-0.0026 \mathrm{X}+3.39991, R^{2}=0.9971$; $135{ }^{\circ} \mathrm{C}, \mathrm{y}=-0.002 \mathrm{X}+3.3724, R^{2}=0.7525 ; 120^{\circ} \mathrm{C}$, $\mathrm{y}=-0.0005 \mathrm{X}+3.2828, R^{2}=0.8177$. The activation energy of the delignification of the pretreated sawdust waste was derived using Equation (5) from the slope of $\ln \mathrm{k}$ against $1 / \mathrm{T}$. The activation energy value was calculated to be $76.4 \mathrm{~kJ} / \mathrm{mole}$ and the Arrhenius constant was $8.4 \times 10^{6} / \mathrm{min}$ (Figure 2(B)). Activation energies for some lignocelluloses have been reported in the scientific literature (Kim and Holtzapple, 2006). In alkaline conditions, corn stover and sugarcane bagasse may have more favourable structures than wood and, as a result, lower activation energies for delignification (Kim and Hotlzapple, 2006). Corn stover and sugarcane bagasse under alkaline conditions were reported to have activation energies of $54.21 \mathrm{~kJ} / \mathrm{mol}$ and $31.47 \mathrm{~kJ} / \mathrm{mol}$, respectively (Kim and Holtzapple, 2006; Fuentes et al., 2011). With oxidative pretreatment, the activation energies for kraft delignification of wood were reported to vary between 110-130 kJ/mol (Kim and Holtzapple, 2006, Dolk et al. 1989). Therefore, for delignification in alkaline conditions, most non-woody lignocelluloses have lower delignification activation energies than woody biomass. In this study, the activation energy, $74.6 \mathrm{~kJ} / \mathrm{mol}$, for the Shea tree sawdust is higher than values for some non-woody lignocelluloses. As a result, in the light of the prevailing pretreatment conditions, the activation energy of Shea tree sawdust has been established. However, compared to some other woody biomass, the value of $74.6 \mathrm{~kJ} / \mathrm{mol}$ is lower. The value of the rate constant, $\mathrm{k}$, is said to be affected by the chemical concentration during pretreatments and the structural features of the biomass (Miguel et al., 1999). At a temperature between $110-200{ }^{\circ} \mathrm{C}$, the activation energies during delignification of Eucalyptus globulus varied between $31.8 \mathrm{~kJ} / \mathrm{mol}$ and $98.4 \mathrm{~kJ} / \mathrm{mol}$, which were below the values reported by Kim and Holtzapple (2006) and Dolk et al., (1989). Several other authors also reported that wood particle size and diffusion reactions have effects on alkaline penetration during pretreatments (Dang and Nguyen, 2008). The discrepancy in delignification activation energy of the Shea tree sawdust relative to other woody biomass under the prevailing pretreatment conditions, could be due to the variations in pretreatment conditions. Furthermore, the very stable conditions of lignin during pretreatments may have accounted for the differences.

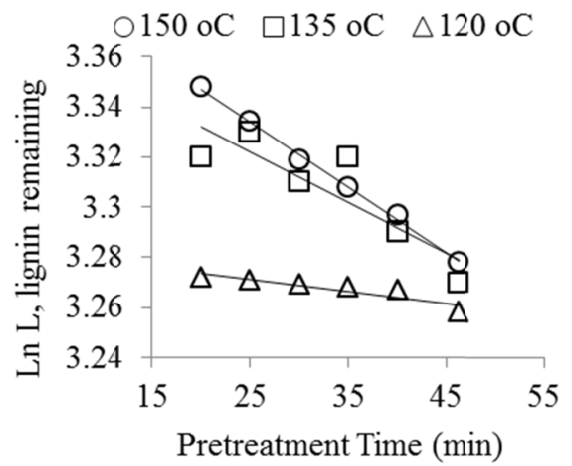

(A)

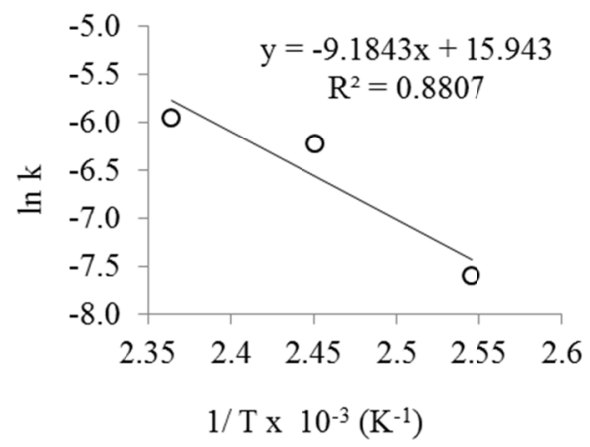

(B)

Figure 2: Kinetics of delignification based on residual lignin content. (A) logarithmic plots for lignin remaining at the operating temperatures after pretreatment versus time; (B) Arrhenius plot of the treated biomass. 


\section{Effect of Enzymatic Hydrolysis on Treated and Untreated Biomass}

Our earlier studies established that a combination of air and hydrogen peroxide as oxidizing agents increased the delignification of Vitellaria paradoxa sawdust leading to increased enzymatic hydrolysis of treated biomass (Ayeni et al., 2013a; Ayeni et al., 2013b; Ayeni et al., 2014). It was pointed out that, under the optimized pretreatment conditions $\left(150{ }^{\circ} \mathrm{C}\right.$, $45 \mathrm{~min}, 1 \% \mathrm{H}_{2} \mathrm{O}_{2}$, and $1.0 \mathrm{MPa}$ air pressure), at $2 \%$ pretreated biomass loading, enzymatic hydrolysis temperature of $50{ }^{\circ} \mathrm{C}$, and hydrolysis period of $72 \mathrm{~h}$, the total reducing sugars obtained were $263.49 \mathrm{mg}$ equivalent glucose/g dry biomass. Defining a single optimum for enzymatic hydrolysis is impossible. End products of the hydrolysis (mainly cellobiose and glucose, which may also include the furan compounds as furan and hydroxylmethyl furfural (HMF)) (Andrić et al., 2010) may also inhibit the enzyme activity, the build-up of any of these products negatively affects cellulose hydrolysis. The concentration of the cellulase enzyme complex has a high impact on the conversion of the cellulose. The maximum cellulase activity for most fungal-derived cellulases and $\beta$-glucosidase was reported to occur at $50 \pm 5{ }^{\circ} \mathrm{C}$ and a pH between 4.0 and 5.0 (Gregg et al., 1998). At lower temperatures, the hydrolysis rate per unit of active enzyme is slower, but so is enzyme denaturation (Kaar and Holtzapple, 2000). The optimum temperature and $\mathrm{pH}$ is not only a function of the raw material and the enzyme source, but is also highly dependent on the hydrolysis time. The optimal conditions change with the hydrolysis residence time (Tengborg et al., 2001), and are also dependent on the source of the enzymes. In order to improve on our previous studies (Ayeni et al., 2013a; Ayeni et al., 2014), enzymatic digestibility was evaluated considering increasing substrate concentrations, hydrolysis time, and hydrolysis temperature, as well as increasing enzyme loadings. The effects of substrate concentration variation $(20,30,40$, and $50 \mathrm{~g} / \mathrm{L})$ with and without supplemental $\beta$-glucosidase, hydrolysis temperature $\left(45^{\circ} \mathrm{C}\right)$, enzyme loadings, as well as hydrolysis time $(96 \mathrm{~h})$ on digestibility were investigated as pretreatment conditions. The results for the pretreated sawdust material after saccharification for the pretreatment conditions $150^{\circ} \mathrm{C}, 1 \% \mathrm{H}_{2} \mathrm{O}_{2}, 1.0$ MPa air pressure are given in Table 2. The effects of substrate concentration variation $(20,30,40$, and 50 $\mathrm{g} / \mathrm{L})$ with and without supplemental $\beta$-glucosidase, hydrolysis temperature $\left(45^{\circ} \mathrm{C}\right)$, and enzyme loadings, as well as hydrolysis time (96 h), on digestibility were investigated in the pretreatment conditions.
With a cellulase enzyme loading of $25 \mathrm{FPU} / \mathrm{g}$ treated substrate, the reducing sugar yield was $187.03 \mathrm{mg} / \mathrm{g}$ dry biomass in $72 \mathrm{~h}$. A higher reducing sugar yield (274 mg/g dry biomass) was obtained with the same enzymatic hydrolysis but different pretreatment conditions; $170{ }^{\circ} \mathrm{C}, 1.0 \mathrm{MPa}$, and $10 \mathrm{~min}$ (Ayeni et al., 2013a). The effect of temperature on biomass pretreatment and enzymatic hydrolysis may have accounted for this variation. In this study, the results showed that reducing sugar yields increased with 20 , $30,40 \mathrm{~g} / \mathrm{L}$ substrate concentrations considered up to the fourth day of hydrolysis. It showed that more sugar is likely to be produced if the hydrolysis time was increased beyond $96 \mathrm{~h}$. The optimum temperature and $\mathrm{pH}$ are not only a function of the raw material and enzyme source, but are also highly dependent on the hydrolysis time (Martín, et al., 1988). This also showed that the enzymes were still active to cause more hydrolysis at the reduced hydrolysis temperature of $45^{\circ} \mathrm{C}$. However, for $50 \mathrm{~g} / \mathrm{L}$ substrate concentration and $62.5 \mathrm{FPU} / \mathrm{g}$ dry biomass loading, the sugar yield was $411.07 \mathrm{mg}$ glucose equivalent $/ \mathrm{g}$ dry biomass, which was lower than the sugar yield at $40 \mathrm{~g} / \mathrm{L}$ and $50 \mathrm{FPU} / \mathrm{g}$ dry biomass loading (448.06 $\mathrm{mg} / \mathrm{g}$ dry biomass). Increasing the substrate concentration to $50 \mathrm{~g} / \mathrm{L}$ caused decreased hydrolysis, despite increased enzyme loadings. This is probably due to end product inhibition, other inhibitors or inefficient mixing. Furthermore, reducing sugar yields without supplemental $\beta$-glucosidase were comparable to when the enzyme was added. For example, at $40 \mathrm{~g} / \mathrm{L}$ substrate concentration and a 50 FPU/g treated substrate enzyme loading, the reducing sugars yield after $96 \mathrm{~h}$ with $\beta$-glucosidase was $448.06 \mathrm{mg} / \mathrm{g}$ dry biomass, while under the same condition but without $\beta$-glucosidase supplement the reducing sugars yield was $399.28 \mathrm{mg} / \mathrm{g}$ dry biomass. This is just about $11 \%$ lower. Addition of cellobiase ( $\beta$-glucosidase) has been reported to greatly increase pretreated biomass conversion. However, increasing cellobiase loading beyond a limit may not enhance biomass digestibility. Zhu (2005) reported that beyond 28.4 CBU/g dry biomass cellobiase loading, the digestibility of pretreated corn stover did not improve. Crude enzymes with high cellobiase activity are less affected by supplemental cellobiase and commercial enzyme sources may also differ in resident cellobiase (Zhu, 2005). The discrepancy could also be attributed to the amount of $\beta$-glucosidase added and the extent of hydrolysis, which depends highly on structural features and cellulase loading (Zhu, 2005; Pu et al., 2013). Therefore, for the economy of the studied process, the absence of $\beta$-glucosidase generally gave better results of digestibility 
than adding $\beta$-glucosidase supplements. However, finding an optimum level of addition offers a challenge for future study. The yields of reducing sugar with no $\beta$-glucosidase addition may be due to the reduction in the inhibitive effects of glucose on the enzyme.

Figure 3 shows the enzymatic hydrolysis results for untreated biomass samples and treated samples with no supplemental $\beta$-glucosidase. The untreated and washed raw biomass was used as the control for comparing the enzymatic digestibility of the treated sawdust. Concentrations in prime notation indicate enzymatic hydrolysis of treated samples.

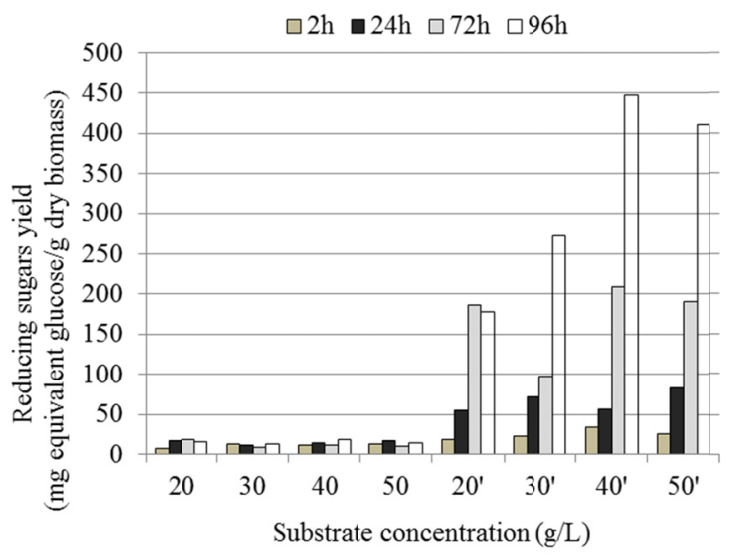

Figure 3: 4-d Effect of time and substrate concentration on the sugar yield for untreated and treated biomass. Concentrations in prime notation indicate enzymatic hydrolysis of pretreated samples. Pretreatment conditions: $150{ }^{\circ} \mathrm{C}, 1 \% \mathrm{H}_{2} \mathrm{O}_{2}, 1.0 \mathrm{MPa}, 45 \mathrm{~min}$. Enzyme hydrolysis conditions: same conditions as indicated in Table 2.

The substrate concentration variation $(20,30,40$, and $50 \mathrm{~g} / \mathrm{L}$ ) with corresponding increase in enzyme loadings and supplemental $\beta$-glucosidase on digestibility were investigated. Chang et al., (2001) investigated the effects of pretreatment time and temperature of poplar wood (lignin content of about $25 \%$ ) on enzymatic hydrolysis and concluded that oxidative lime pretreatment enhanced the reducing sugar yields from $62 \mathrm{mg}$ equivalent glucose/g dry biomass (untreated) to as much as $622 \mathrm{mg}$ equivalent glucose $/ \mathrm{g}$ dry biomass (treated at $150{ }^{\circ} \mathrm{C}$ and $6 \mathrm{~h}$ ). In this study, using the substrate concentration variations with corresponding increases in enzymes loadings, the treated biomass reducing sugars concentration was $399.28 \mathrm{mg} / \mathrm{g}$ dry biomass as compared to untreated material of $19.08 \mathrm{mg} / \mathrm{g}$ dry biomass (Figure 3). The maximum reducing sugar yield in this study under the conditions specified was $42.4 \%$ lower than that reported for poplar wood (Chang et al., 2001). The difference in values may have been caused by raw material composition, pretreatment conditions, efficiency of the different enzymes used, enzyme concentration, and reaction period.

\section{Enzyme Loading Studies}

Whether there are significant yield benefits from loadings higher than $25 \mathrm{FPU} / \mathrm{g}$ dry biomass or whether cellulase loadings less than $25 \mathrm{FPU} / \mathrm{g}$ biomass were sufficient was also investigated (Figure 4).

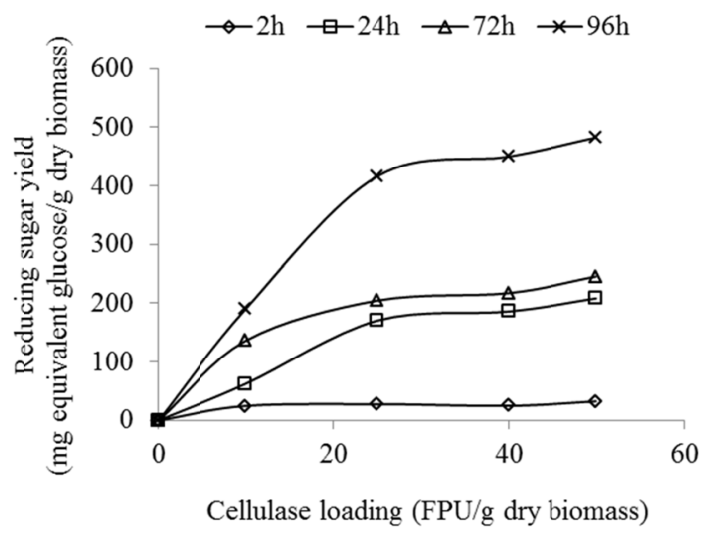

Figure 4: 4-d Effect of enzyme loading on sugar yields. Pretreatment conditions: $150{ }^{\circ} \mathrm{C}, 1 \% \mathrm{H}_{2} \mathrm{O}_{2}, 1.0 \mathrm{MPa}$, $45 \mathrm{~min}$. Enzyme hydrolysis conditions: $5 \mathrm{UI} \beta$-glucosidase/g dry biomass, $45^{\circ} \mathrm{C}$ hydrolysis temperature, $\mathrm{pH} 4.8,40 \mathrm{~g} / \mathrm{L}$ substrate concentration.

Sugar yields with lower enzyme loadings $(1,3,5$, 7, 10 and $15 \mathrm{FPU} / \mathrm{g}$ dry biomass) exist in the scientific literature (Kaar and Holtzapple, 2000; Martín et al., 1988). After lime pretreatment of corn stover, with $10 \mathrm{FPU} / \mathrm{g}$ dry biomass enzyme loading at $40{ }^{\circ} \mathrm{C}$ incubation temperature and $100 \mathrm{~h}$, Kaar and Holtzapple (2000) concluded that the optimum reducing sugars yield was about $610 \mathrm{mg} / \mathrm{g}$ dry biomass. Palonen et al., (2004) investigated wet air oxidation pretreated (at $200^{\circ} \mathrm{C}$ ) softwood enzymatic hydrolysis to reducing sugar using two cellulase mixtures with loadings corresponding to 5, 10, $30 \mathrm{FPU} / \mathrm{g}$ dry biomass. They discovered that using the highest load of $30 \mathrm{FPU} / \mathrm{g}$ dry biomass, under hydrolysis conditions of $40{ }^{\circ} \mathrm{C}, 20 \mathrm{~g} / \mathrm{L}$ substrate concentration for $24 \mathrm{~h}$, maximum sugar yield of $257 \mathrm{mg} / \mathrm{g}$ dry biomass $(55 \%$ conversion of polysaccharide) was achieved. The low sugar yield was partly caused by the low lignin removal during pretreatment (between $24-42 \%$ lignin in the softwood was removed). In this study, the enzyme loading results shown in Figure 4 contain some important features. Higher reducing sugar yields were obtained at higher enzyme loadings (for 
example $25 \mathrm{FPU}$ to $50 \mathrm{FPU} / \mathrm{g}$ dry biomass in the 4day hydrolysis time. The 4-day reducing sugar yield at $50 \mathrm{FPU} / \mathrm{g}$ dry biomass for $150{ }^{\circ} \mathrm{C}, 1 \% \mathrm{H}_{2} \mathrm{O}_{2}, 1.0$ $\mathrm{MPa}$ air pressure, $45 \mathrm{~min}$ pretreatment conditions was $482.40 \mathrm{mg} / \mathrm{g}$ dry biomass, while at $25 \mathrm{FPU} / \mathrm{g}$ dry biomass the yield was $416.32 \mathrm{mg} / \mathrm{g}$ dry biomass (about a 22-fold increase compared to untreated biomass). The $25 \mathrm{FPU} / \mathrm{g}$ dry biomass loading was found to be adequate with this material (Figure 4), but further improvements in pretreatment efficiency would enable decreasing to more economical enzyme dosages. Further inspections show that the sugar yield was about 2.5 times higher after $96 \mathrm{~h}(416.32 \mathrm{mg} / \mathrm{g})$ from the $24 \mathrm{~h}(170.51 \mathrm{mg} / \mathrm{g})$ hydrolysis period. It is expected that, at longer periods and low temperature (in this case $45^{\circ} \mathrm{C}$ ), hydrolysis should increase until a constant value is attained in which the enzymes were supposed to have been exhausted or their actions stopped by inhibitors. Cellulase loadings greater than $25 \mathrm{FPU} / \mathrm{g}$ dry biomass may have caused the cellulose sites to be saturated by the enzymes.

\section{Fermentation of Treated Biomass}

After $72 \mathrm{~h}$ fermentation, the quantity of ethanol obtained $(\mathrm{g} / \mathrm{L})$ at $2 \%$ effective cellulose loading was $10.69 \mathrm{~g} / \mathrm{L}$ (\% theoretical ethanol yield: $31.03 \%)$ for pretreatment at $150{ }^{\circ} \mathrm{C}, 1 \% \mathrm{H}_{2} \mathrm{O}_{2}, 1.0 \mathrm{MPa}$ air pressure, and $45 \mathrm{~min}$. At an increased effective cellulose loading of $3 \%$, the ethanol obtained did not significantly increase $(12.43 \mathrm{~g} / \mathrm{L}$ with theoretical ethanol yield of $29.56 \%$ ). The \% theoretical ethanol yields (based on cellulose conversion) for the pretreatment conditions were higher at $2 \%$ effective cellulose loading than at $3 \%$ effective cellulose loading. The ethanol concentration tended to be higher at 3\% substrate loading, but at this loading the \% theoretical ethanol yields were much lower than that at $2 \%$ substrate loading. This implies that more of the cellulose was converted at $2 \%$ loading than at $3 \%$ substrate loading. The ethanol yield at 3\% loading showed that more reducing sugar was produced by enzymatic hydrolysis and was probably more quickly assimilated by yeast for cell growth and ethanol production than at $2 \%$ loading. For the $96 \mathrm{~h}$ fermentation period, the corresponding ethanol values for the $2 \%$ and $3 \%$ biomass loadings did not appreciably increase. At $2 \%$ effective cellulose loading, the quantity of ethanol obtained was $12.73 \mathrm{~g} / \mathrm{L}$ (32.75\% theoretical ethanol yield). The $3 \%$ cellulose loading it corresponded to $13.84 \mathrm{~g} / \mathrm{L}$ with $33.44 \%$ theoretical ethanol yield. The ethanol yield at 2\% cellulose loading was comparable to the $3 \%$ cellulose loading. Yeast may have acted faster on the $2 \%$ cellulose loading than the 3\% cellulose loading. At high cellulose loading, the increased glucose monomers may also be inhibiting the actions of the microbes. Cellulose conversion at $2 \%$ substrate loading should be more appropriate for the SSF under the conditions considered. However, more of the substrate will be needed for the fermentation process. Generally, the low ethanol yield in this study is connected to the high lignin content because cellulose accessibility to cellulases is largely limited by the anatomical structure of the plant cell wall ( $\mathrm{Pu}$ et al., 2013). Lignin interferes with enzymatic hydrolysis by blocking access to cellulase and irreversibly binding hydrolytic enzyme. Lignin inhibits the enzymes during hydrolysis. In future studies, to remedy and reduce the recalcitrant nature of the biomass, addition of extra nutrients and minerals [in the form of yeast extract, bacto tryptone (casein extract)] to the fermentation broth will be taken into consideration. Extra nutrients and minerals can increase the ethanol concentration at very short incubation periods (Lissens et al., 2004). Furthermore, a combination of both hemicellulase and cellulase enzymes could cause increased enzymatic hydrolysis in the biomass-to-ethanol process.

\section{CONCLUSIONS}

This study proved the efficiency of alkaline peroxide oxidation pretreatment on a woody biomass, Vitellaria paradoxa (Shea tree) sawdust. The pretreatment caused appreciable disruption of the biomass structure making cellulose more accessible to the enzymatic complex. Significant increases in reducing sugar yield were observed for the treated relative to the untreated biomass. For the kinetics of delignification, the results indicated the activation energy to be $76.4 \mathrm{~kJ} / \mathrm{mole}$ and the Arrhenius constant was calculated as $8.4 \times 10^{6} / \mathrm{min}$. After pretreatment (optimized conditions of $150{ }^{\circ} \mathrm{C}, 1 \% \mathrm{H}_{2} \mathrm{O}_{2}, 1.0 \mathrm{MPa}$ air pressure, $45 \mathrm{~min}$ ) and enzymatic hydrolysis (digestibility conditions of $45^{\circ} \mathrm{C}, 96 \mathrm{~h}, \mathrm{pH} 4.8$ at 40 $\mathrm{g} / \mathrm{L}$ substrate loading), the reducing sugar yield for the treated biomass was $347.20 \mathrm{mg} / \mathrm{g}$ dry biomass. Optimization of the enzymatic digestibility with the enzyme loading studies for the 4-day incubation period showed that a $25 \mathrm{FPU} / \mathrm{g}$ dry biomass enzyme loading yielded $416.32 \mathrm{mg} / \mathrm{g}$ dry biomass for $40 \mathrm{~g} / \mathrm{L}$ substrate concentration, compared to the $19.08 \mathrm{mg} / \mathrm{g}$ dry biomass reducing sugar yield of the untreated sample. Therefore, under the optimized conditions more of the substrate will be needed for the enzymatic hydrolysis process. Conversion of the treated woody material to ethanol at $2 \%$ effective cellulose 
loading after $96 \mathrm{~h}$ fermentation by Saccharomyces cerevisiae was $12.73 \mathrm{~g} / \mathrm{L}$. In all, the Shea tree was found to be challenging due to the high lignin content. However, in an integrated bio-refinery, the undissolved lignin can be available for energy production by combustion, and for conversion to other fuels and chemicals.

As a result of the recalcitrant nature of the biomass, further improvements in pretreatment and the enzymatic digestibility are needed.

\section{ACKNOWLEDGEMENTS}

The author (A.O.A) is grateful to the Council of Scientific and Industrial Research (CSIR), New Delhi, India and The World Academy of Sciences for the Advancement of Science in Developing Countries (TWAS), Italy, for the award of a CSIR-TWAS fellowship for Research and Advanced Training tenable at National Environmental Engineering Research Institute (NEERI), Nagpur, India. The Nigerian Conservation Foundation and Chevron Nigeria Limited are appreciated for the Chief S.L. Edu research grant award. Also appreciated is the management of Covenant University, Ota, Nigeria for granting a one-year leave for this study.

\section{REFERENCES}

Ayeni, A. O., Omoleye, J. A., Mudliar, S. N., Hymore, F. K. and Pandey, R. A., Utilization of lignocellulosic waste for ethanol production: Enzymatic digestibility and fermentation of pretreated shea tree sawdust. Korean Journal of Chemical Engineering, 31(7), 1180-1186 (2014).

Ayeni, A. O., Banerjee, S., Omoleye, J. A., Hymore, F. K., Giri, B. S., Deskmukh, S. C., Pandey, R. A. and Mudliar, S. N., Optimization of pretreatment conditions using full factorial design and enzymatic convertibility of shea tree sawdust. Biomass and Bioenergy, 48, 130-138 (2013a).

Ayeni, A. O., Hymore, F. K., Mudliar, S. N., Deskmukh, S. C., Satpute, D. B., Omoleye, J. A. and Pandey, R. A., Hydrogen peroxide and lime based oxidative pretreatment of wood waste to enhance enzymatic hydrolysis for a biorefinery: Process parameters optimization using response surface methodology. Fuel, 106, 187-194 (2013b).

Andrić, P., Meyer, A. S., Jensen, P. A. and DamJohansen, K., Reactor design for minimizing product inhibition during enzymatic lignocellulosic hydrolysis II. Quantification of inhibition and suitability of membrane reactors. Biotechnology Advances, 28, 407-425 (2010).

Bailey, M. J. and Linko, M., Production of $\beta$-glucosidase by Aspergillus oryzae in submerged bioreactor cultivation. Journal of Biotechnology, 16, 57-66 (1990).

Bennet, C., Spectrophotometric acid dichromate method for the determination of ethyl alcohol. American Journal of Medical Technology, 37, 217-220 (1971).

Blasi, C. D., Signorelli, G., Di Russo, C. and Rea, G., Product distribution from pyrolysis of wood and agricultural residues. Industrial Engineering and Chemistry Research, 38, 2216-2224 (1999).

Chang, V. S., Nagwani, M., Kim, C. and Holtzapple, M. T., Oxidative lime pretreatment of high-lignin biomass. Applied Biochemistry and Biotechnology, 94, 1-28 (2001).

Chang, V. S., Nagwani, M. and Holtzapple, M. T., Lime pretreatment of crop residues bagasse and wheat straw. Applied Biochemistry Biotechnology, 74, 135-159 (1998).

Correira, F., Roy, D. N. and Goel, K., Chemistry and delignification kinetics of Canadian industrial hemp. Journal of Wood Chemistry and Technology, 21, 97-111 (2001).

Dang V. O. and Nguyen K. L., A universal kinetic model for characterization of the effect of chip thickness on kraft pulping. Bioresource Technology, 99, 1486-1490 (2008).

Dolk, M., Yan, J. F. and McCarthy, J. L., Lignin 25. Kinetics of delignification of western hemlock in flow through reactors under alkaline conditions. Holzforschung, 43(2), 91-98 (1989).

Dowe, N. and McMillan, J., SSF experimental protocols: Lignocellulosic biomass hydrolysis and fermentation: Laboratory analytical procedure (LAP). Golden, CO: National Renewable Energy Laboratory; Jan. NREL Report No.: TP-510-42630. Contract No.: DE-AC36-99-G010337. Sponsored by the U.S. Department of Energy (2008).

Esteves, B., Gominho, J., Rodrigues, J. C., Miranda, I. and Pereira, H., Pulping yield and delignification kinetics of heartwood and sapwood of maritime pine. Journal of Wood Chemistry and Technology, 25, 217-230 (2005).

Fuentes, L. G., Rabelo, S. C., Filho, R. M. and Costa, A. C., Kinetics of lime pretreatment of sugarcane bagasse to enhance enzymatic hydrolysis. Applied Biochemistry and Biotechnology, 163, 612625 (2011).

Ghose, T. K., Measurement of cellulase activities. Pure and Applied Chemistry, 59, 257-268 (1987).

Gould, J. M., Alkaline peroxide delignification of 
agricultural residues to enhance enzymatic saccharification. Biotechnology and Bioengineering, 26, 46-52 (1984).

Gould, J. M., Jasberg, B. K., Fahey, G. C. and Berger, L. L., Treatment of wheat straw with alkaline hydrogen peroxide in a modified extruder. Biotechnology and Bioengineering, 33, 233-236 (1989).

Gregg, D. J., Boussaid, A. and Saddler, J. N., Technoeconomic evaluation of a generic wood to-ethanol process: Effect of increased cellulose yields and enzyme recycle. Bioresource Technology, 63, 712 (1998).

Kaar, W. E. and Holtzapple, M. T., Using lime pretreatment to facilitate the enzyme hydrolysis of corn stover. Biomass and Bioenergy, 18, 189-199 (2000).

Kim, S. and Holtzapple, M. T., Delignification kinetics of corn stover in lime pretreatment. Bioresource Technology, 97, 778-785 (2006).

Kim, T. H. and Lee, Y. Y., Fractionation of corn stover by hot-water and aqueous ammonia treatment. Bioresource Technology, 97, 224-232 (2006).

Kleinert, T. N., Mechanisms of alkaline delignification 1 . The overall reaction pattern. Tappi Journal, 49, 53-57 (1996).

Kleinert, T. N., Ethanol-water delignification of wood. Rate constants and activation energy. Tappi Journal, 58, 170-171 (1975).

Krishna, S. H. and Chowdary, G. V., Optimization of simultaneous saccharification and fermentation for the production of ethanol from lignocellulosic biomass. Journal of Agricultural and Food Chemistry, 48, 1971-1976 (2000).

Kristensen, M. and Lykke, A. M., Informant-based evaluation of use and conservation preferences of savanna trees in Burkina Faso. Economic Botany, 57(2), 203-217 (2003).

Kumar, P., Barrett, D. M., Delwiche, M. J. and Stroeve, P., Methods for pretreatment of lignocellulosic biomass for efficient hydrolysis and biofuel production. Industrial Engineering Chemistry Research, 48, 3713-3729 (2009).

Ladisch, M. R, Flickinger, M. C. and Tsao, G. T., Fuels and Chemicals from biomass. Energy, 4(2), 263-275 (1979).

Li, S., Xu, S., Liu, S., Yang, C. and Lu, Q., Fast pyrolysis of biomass in free-fall reactor for hydrogen-rich gas. Fuel Process Technology, 85, 12011211 (2004).

Li, Z., Chen, C. H., Hegg, E. L. and Hodge, D. B., Rapid and effective oxidative pretreatment of woody biomass at mild reaction conditions and low oxidant loadings. Biotechnology for Biofuels, 6, 19 (2013).
Lin, L., Yan, R., Liu, Y. and Jiang, W., In-depth investigation of enzymatic hydrolysis of biomass wastes based on three major components: Cellulose, hemicellulose, and lignin. Bioresource Technology, 101, 8217-8223 (2010).

Lissens, G., Klinke, H., Verstraete, W., Ahring, B. and Thomsen, A. B., Wet oxidation pretreatment of woody yard waste: Parameter optimization and enzymatic digestibility for ethanol production. Journal of Chemical Technology and Biotechnology, 79, 889-895 (2004).

Martín, C., Negro, M. J., Alfonsel, M. and Sáez, R., Enzymatic hydrolysis of lignocellulosic biomass from Onopordum nervosum. Biotechnology and Bioengineering, 32, 341-344 (1988).

Miguel, A. G., Rodriguez, F., Santos, A., Oliet, M., Garcia-Ochoa, F. and Tijero, J., Kinetics of Eucalyptus globulus delignification in methanol-water medium. Industrial Engineering and Chemistry Research, 38, 3324-3322 (1999).

Miller, G. L., Use of dinitrosalicylic acid reagent for determination of reducing sugar. Analytical Chemistry, 31, 426-428 (1959).

Mosier, N., Wyman, C. E., Dale, B., Elander, R., Lee, Y. Y., Holtzapple, M. T. and Ladish, M., Features of promising technologies for pretreatment of lignocellulosic biomass. Bioresource Technology, 96, 673-686 (2005).

Nelson, P. J. and Gniel, G. M., Delignification of Eucalyptus woods during alkali pulping. 4th International Symposium on Wood and Pulping Chemistry, 125-129 (1987).

Palonen, H., Thomsen, A. B., Tenkanen, M., Schmidt, A. S. and Viikari, L., Evaluation of wet oxidation pretreatment for enzymatic hydrolysis of softwood. Applied Biochemistry and Biotechnology, 117, 1-17 (2004).

Parajó, J. C., Alonso, J. L. and Santos, V., Kinetics of catalysed organosolv processing of pine wood. Industrial and Engineering Chemistry Research, 34, 4333-4341 (1995).

$\mathrm{Pu}$, Y., Hu, F., Huang, F., Davidson, B. H. and Ragauskas, A. J., Accessing the molecular structure basis for biomass recalcitrance during dilute acid and hydrothermal pretreatments. Biotechnology for biofuels, 6, 15, (2013).

Qi, B., Chen, X., Shen, F., Su, Y. and Wan, Y., Optimization of enzymatic hydrolysis of wheat straw pretreated by alkaline peroxide using response surface methodology. Industrial and Engineering Chemistry Research, 48, 7346-7353 (2009).

Sallé, J., Boussim, A., Raynal-Roques, A. and Brunck, F., Potential wealth of the Shea nut tree. Research perspective for improving yield. Bois et Foréts 
des Tropiques, 228, 11-23 (1991).

Sluiter, A., Hames, B., Ruiz, R., Scarlata, C., Sluiter, J., Templeton, D. and Croker, D., Determination of structural carbohydrates and lignin in biomass: Laboratory analytical procedure (LAP). Golden, CO: National Renewable Energy Laboratory; April. NREL Report No.: TP-510-42618. Contract No.: DE-AC36-99-G010337. Sponsored by the U.S. Department of Energy (2008).

Springer, E. L., Harris, J. F. and Neil, W. K., Rate studies of the hydrotropic delignification of aspen wood. Tappi Journal, 46, 551-555 (1963).

Tengborg, C., Galbe M. and Zacchi, G., Influence of enzyme loading and physical parameters on the enzymatic hydrolysis of steam pretreated softwood. Biotechnology Progress, 17, 110-117 (2001).

Vázquez, G., Antorrena, G. and Gonzalez, J., Ki- netics of acid-catalysed delignification of Eucalyptus globulus wood by acetic acid. Wood Science and Technology, 29, 267-275 (1995).

Wei, C. J. and Cheng, C. Y., Effect of hydrogen peroxide pretreatment on the structural features and the enzymatic hydrolysis of rice straw. Biotechnology and Bioengineering, 27, 1418-1426 (1985).

Yoo, C. G., Lee, C. W. and Kim, T. H., Optimization of two stage fractionation process for lignocellulosic biomass using response surface methodology (RSM). Biomass and Bioenergy, 35, 49014909 (2011).

Zhu, L., Fundamental Study of Structural Features Affecting Enzymatic Hydrolysis of Lignocellulosic Biomass. Ph.D. Dissertation, Texas A\&M University, College Station (2005). 